\title{
The control of marine biofouling on xerogel surfaces with nanometer-scale topography
}

Nikhil Gunari, Lenora H. Brewer, Stephanie M. Bennett, Anastasiya Sokolova, Nadine D. Kraut , John A. Finlay, Anne E. Meyer, Gilbert C. Walker, Dean E. Wendt, Maureen E. Callow, James A. Callow , Frank V. Bright and Michael R. Detty

\begin{abstract}
Mixtures of $n$-octadecyltrimethoxysilane (C18, 1-5 mole-\%), n-octyltriethoxysilane (C8) and tetraethoxysilane (TEOS) gave xerogel surfaces of varying topography. The 1:49:50 C18/C8/TEOS xerogel formed 100-400-nm-wide, $2-7-n m$ deep pores by AFM while coatings with $\geq 3 \% \mathrm{C} 18$ were free of such features. Segregation of the coating into alkane-rich and alkane-deficient regions in the 1:49:50 C18/C8/TEOS xerogel was observed by IR microscopy. Immersion in ASW for $48 \mathrm{~h}$ gave no statistical difference in surface energy for the 1:49:50 C18/C8/TEOS xerogel and a significant increase for the 50:50 C8/TEOS xerogel. Settlement of barnacle cyprids and removal of juvenile barnacles, settlement of zoospores of the alga Ulva linza, and strength of attachment of 7-day sporelings were compared amongst the xerogel formulations. Settlement of barnacle cyprids was significantly lower in comparison to glass and polystyrene standards. The 1:49:50 and 3:47:50 C18/C8/TEOS xerogels were comparable to PDMSE with respect to removal of juvenile barnacles and sporeling biomass, respectively.
\end{abstract}

\section{Introduction}

Biofouling on ships' hulls is a significant problem worldwide causing an increase in fuel consumption due to drag (Schultz 2007; Schultz et al. 2010) as well as mediating the spread of non-indigenous species (reviewed by Piola et al. 2009). Since the use of biocides in antifouling (AF) paints is becoming increasingly restricted (see Thomas and Brooks 2010), a significant research effort is focused on the development of environmentally benign technologies to control fouling. Organically-modified, hybrid xerogel coatings have been shown to possess AF and fouling-release (FR) characteristics (Tang et al. 2005; McMaster et al. 2009; Bennett et al. 2010; Finlay et al. 2010). Approximately 100 boats have been coated with an organicallymodified, hybrid xerogel (AquaFast ${ }^{\mathbb{R}}$ ) and the same material has been used to minimize biofouling on the monitoring system of an underwater archaeological site (Selvaggio et al. 2009).

The xerogel surfaces examined to date are inexpensive and robust, characterized by uniform surface roughness/topography, and cover a wide range of wettabilities $\left(35-105^{\circ}\right.$, as measured by the static water contact angle, $\theta_{\mathrm{Ws})}$ and surface energies (21$55 \mathrm{mN} \mathrm{m}^{-1}$, Bennett et al. 2010). The settlement of barnacle cyprids and algal zoospores is highly correlated with surface energies and surface wettabilities as is the removal of algal (Ulva) sporelings (young plants) and adhered diatoms (Bennett et al. 2010; Finlay et al. 2010). However, the response to these surface parameters is not uniform: cypris larvae of Balanus amphitrite prefer to settle on xerogel surfaces with high wettability and high surface energy (Finlay et al. 2010) while zoospores of Ulva prefer to settle on hydrophobic xerogel surfaces with low surface energy (Bennett et al. 2010). Sporelings of Ulva are more readily removed from surfaces with low wettability and low surface energy (Bennett et al. 2010) while diatoms are more readily removed from surfaces with high wettability and high surface energy (Finlay et al. 2010). The adhesion of proteins to the xerogel surfaces follows the "Baier curve" (Baier et al. 1968; Baier 1984; Baier and Meyer 1992) with higher adhesion at both low and high surface energies and minimal adhesion near a critical surface tension, $\gamma_{C}$, of $20-25 \mathrm{mN} \mathrm{m}^{-1}$. Juvenile barnacles are not readily removed from any of the 
xerogel surfaces from prior studies although some success has been noted on hydrophobic surfaces with low surface energy (Tang et al. 2005).

Nature in her diversity has created a situation where no single surface can have appropriate wettability to minimize adhesion and settlement and to optimize release of micro- and macrofouling of all types. The design of AF and FR surfaces for marine applications is relevant in the wider context of studies on cell and bacterial adhesion, where topography has been included as a significant component of surface composition in addition to wettability. Nanorods (Lee et al. 2009) and nanowires (Ainslie et al. 2005) have both been shown to reduce the adsorption of proteins and cells on surfaces incorporating them. Polymeric nanocombs and nanobrushes have provided surfaces that minimize the adhesion of biopolymers such as proteins (de Vasconcelos et al. 2007; Cole et al. 2009; Hucknall et al. 2009) and minimize the settlement and adhesion of bacteria (Bernards et al. 2008; Mi et al. 2010). Polymeric nanocombs and nanobrushes also have $\mathrm{AF} /$ foul-release characteristics that minimize settlement and release of marine macrofouling (Gudipati et al. 2005; Krishnan et al. 2006, 2008; Weinman et al. 2009). Nanotexture has been correlated with superhydrophobicity (Genzer and Efimenko 2006; Genzer and Marmur 2008) and improved $\mathrm{AF} / \mathrm{FR}$ of coatings has been attributed to topography at the nanoscale (eg Beigbeder et al. 2008; Finlay et al. 2008b; Majumdar et al. 2008; Akesso et al. 2009; Grozea et al. 2009, Grozea and Walker 2009; Martinelli et al. 2009; Scardino et al. 2009). Patterned surfaces with well-defined distances, typically $2 \mu \mathrm{m}$, between pillars, channels and bioinspired designs such as Sharklet ${ }^{\mathbb{R}}$, have also been effective at minimizing fouling (Schumacher et al. 2007; Long et al. 2010). Recent data suggest that the settlement preference of barnacle cyprids is linked with susceptibility to removal by force, ie cyprids select textures to which they adhere most strongly (Aldred at al. 2010).

Brushes, combs, rods, wires, and nanotexture all describe "protrusions" for surface topography. Surfaces containing nano- or micropores have also shown the ability to reduce protein adsorption and adhesion (Koc et al. 2008). Highly porous materials have been shown to have increased hydrophobicity and Cassiestate wetting in a recent study comparing a density gradient of "holes" to "pillars" on a single surface (Spori et al. 2010).

Herein, hybrid xerogel surfaces incorporating 1-5 mole- $\%$ of an $n$-octadecyltrimethoxysilane (C18) precursor in combination with $n$-octyltriethoxysilane (C8) and tetraethoxysilane (TEOS) are described. The surfaces have comparable critical surface tensions $\left(\gamma_{\mathrm{C}}\right)$ and surface energies $\left(\gamma_{\mathrm{S}}\right)$, but values of $\theta_{\mathrm{Ws}}$ are composition dependent. The question addressed in these studies is whether the surface topography on films of constant surface energy impacts the settlement of cypris larvae of the barnacle B. amphitrite and zoospores of the macrofouling alga Ulva linza and release of juvenile barnacles and Ulva sporelings.

\section{Materials and methods \\ Chemical reagents}

Deionized water was prepared to a specific resistivity of at least $18 \mathrm{M} \Omega$ using a Barnstead NANOpure Diamond UV ultrapure water system. Tetraethoxysilane (TEOS), $n$-octadecyltrimethoxysilane (C18), and $n$-octyltriethoxysilane (C8) were purchased from Gelest, Inc. and were used as received. Ethanol was purchased from Quantum Chemical Corp. Hydrochloric acid was obtained from Fisher Scientific Co. Borosilicate glass microscope slides were obtained from Fisher Scientific, Inc.

\section{Sol preparation}

The sol/xerogel composition is designated in terms of the molar ratio of Si-containing precursors. Thus, a 50:50 C8/TEOS composition contains 50 mole- $\%$ C 8 and 50 mole- $\%$ TEOS. In all of the sol preparations described below, the aqueous $\mathrm{HCl}$ was added last.

\section{0:50 C8/TEOS}

A mixture of TEOS $(2.09 \mathrm{~g}, 2.24 \mathrm{ml}, 10 \mathrm{mmol}), \mathrm{C} 8$ $(2.78 \mathrm{~g}, 3.16 \mathrm{ml}, 10 \mathrm{mmol})$, isopropanol $(4.0 \mathrm{ml})$, and $0.100 \mathrm{~N} \mathrm{HCl}(1.23 \mathrm{ml}, 0.123 \mathrm{mmol})$ was capped and stirred at ambient temperature for $24 \mathrm{~h}$.

\section{5:45:50 C18/C8/TEOS}

A mixture of C18 $(0.269 \mathrm{~g}, 0.720 \mathrm{mmol}, 0.305 \mathrm{ml}), \mathrm{C} 8$ $(1.79 \mathrm{~g}, 6.48 \mathrm{mmol}, 2.03 \mathrm{ml})$, TEOS $(1.50 \mathrm{~g}, 7.20 \mathrm{mmol}$, $1.61 \mathrm{ml}), 0.1 \mathrm{~N} \mathrm{HCl}(0.91 \mathrm{ml}, 0.09 \mathrm{mmol})$, and isopropanol (4.62 $\mathrm{ml})$ was stirred at ambient temperature for $24 \mathrm{~h}$.

\section{4:46:50 C18/C $8 /$ TEOS}

A mixture of C18 (0.215 g, $0.580 \mathrm{mmol}, 0.244 \mathrm{ml}), \mathrm{C} 8$ $(1.83 \mathrm{~g}, 6.62 \mathrm{mmol}, 2.08 \mathrm{ml})$, TEOS $(1.50 \mathrm{~g}, 7.20 \mathrm{mmol}$, $1.61 \mathrm{ml}), 0.1 \mathrm{~N} \mathrm{HCl}(0.91 \mathrm{ml}, 0.09 \mathrm{mmol})$, and isopropanol $(4.62 \mathrm{ml})$ was stirred at ambient temperature for $24 \mathrm{~h}$.

\section{3:47:50 C18/C $8 /$ TEOS}

A mixture of C18 (0.161 g, $0.430 \mathrm{mmol}, 0.183 \mathrm{ml}), \mathrm{C} 8$ $(1.87 \mathrm{~g}, 6.77 \mathrm{mmol}, 2.12 \mathrm{ml})$, TEOS $(1.50 \mathrm{~g}, 7.20 \mathrm{mmol}$, 
$1.61 \mathrm{ml}), 0.1 \mathrm{~N} \mathrm{HCl}(0.91 \mathrm{ml}, 0.09 \mathrm{mmol})$, and isopropanol $(4.62 \mathrm{ml})$ was stirred at ambient temperature for $24 \mathrm{~h}$.

\section{2:48:50 C18/C8/TEOS}

A mixture of $\mathrm{C} 18(0.108 \mathrm{~g}, 0.29 \mathrm{mmol}, 0.122 \mathrm{ml}), \mathrm{C} 8$ $(1.91 \mathrm{~g}, 6.91 \mathrm{mmol}, 2.17 \mathrm{ml})$, TEOS $(1.50 \mathrm{~g}, 7.20 \mathrm{mmol}$, $1.61 \mathrm{ml}), 0.1 \mathrm{~N} \mathrm{HCl}(0.91 \mathrm{ml}, 0.09 \mathrm{mmol})$, and isopropanol (4.62 $\mathrm{ml})$ was stirred at ambient temperature for $24 \mathrm{~h}$.

\section{1:49:50 C18/C8/TEOS}

A mixture of $\mathrm{C} 18(0.054 \mathrm{~g}, 0.14 \mathrm{mmol}, 0.061 \mathrm{ml}), \mathrm{C} 8$ $(1.95 \mathrm{~g}, 7.06 \mathrm{mmol}, 2.21 \mathrm{ml})$, TEOS $(1.50 \mathrm{~g}, 7.20 \mathrm{mmol}$, $1.61 \mathrm{ml}), 0.1 \mathrm{~N} \mathrm{HCl}(0.91 \mathrm{ml}, 0.09 \mathrm{mmol})$, and isopropanol $(4.62 \mathrm{ml})$ was stirred at ambient temperature for $24 \mathrm{~h}$.

\section{Xerogel film formation}

Xerogel films were formed by spin casting $400 \mu$ of the sol precursor onto $25-\mathrm{mm} \times 75-\mathrm{mm}$ glass microscope slides. Prior to use, the slides were soaked in piranha solution for $24 \mathrm{~h}$, rinsed with copious quantities of deionized water, soaked in isopropanol for $10 \mathrm{~min}$, air dried, and stored at ambient temperature. A model P6700 spincoater (Specialty Coatings Systems, Inc.) was used at $100 \mathrm{rpm}$ for $10 \mathrm{~s}$ to deliver the sol and at $3000 \mathrm{rpm}$ for $30 \mathrm{~s}$ to coat.

For barnacle cyprid assays, glass $20-\mathrm{mm} \times 60-\mathrm{mm}$ Petri dish bottoms (VWR Scientific, Inc.) were soaked in piranha solution for $24 \mathrm{~h}$, rinsed with copious quantities of deionized water, and stored in an oven at $110^{\circ} \mathrm{C}$ until use. The Petri dish bottoms were cooled to ambient temperature and $600 \mu \mathrm{l}$ of the appropriate sol precursor were added and the Petri dish was manipulated until the bottom surface and approximately $5 \mathrm{~mm}$ of the side surface were covered. The excess sol precursor was removed by pipette. All coated surfaces (glass slides and Petri dishes) were dried at ambient temperature for at least 7 days prior to analysis.

\section{Imaging transmission infrared (IR) microscopy of xerogel samples}

Imaging transmission IR microscopy was carried out using a Bruker Vertex 70 and Hyperion 3000 IR microscope $\left(4 \mathrm{~cm}^{-1}, 64\right.$ scans, $15 \times$ objective, $64 \times 64$ focal plane array). Samples were prepared by spin casting $400 \mu \mathrm{l}$ of the sol precursor onto 25 $\mathrm{mm} \times 75-\mathrm{mm}$ glass microscope slides and air drying the films at ambient temperature for at least 7 days.
Prior to IR imaging, xerogel films were soaked in doubly deionized water at $25^{\circ} \mathrm{C}$ for $24 \mathrm{~h}$ and then dried at $60^{\circ} \mathrm{C}$ for $2 \mathrm{~h}$.

\section{Atomic force microscopy (AFM) imaging measurements}

In order to determine surface roughness, xerogel samples were imaged using an atomic force microscope (AFM). In initial experiments, xerogel samples were immersed in artificial seawater (ASW) for $1 \mathrm{~h}$, rinsed with deionized water, and then air dried for $2 \mathrm{~h}$. Following immersion for $1 \mathrm{~h}$ in ASW, no significant changes in water contact angle were observed over a 2-h time period for samples dried in the air at ambient temperature. AFM images were obtained using the Molecular Force Probe AFM (Asylum Research, Santa Barbara, CA). Rectangular shaped silicon tips with a radius of curvature of $<8 \mathrm{~nm}$ ( $\mathrm{NCH}_{-} \mathrm{W}$, NanoWorld, Switzerland) and with a nominal spring constant of $42 \mathrm{~N} \mathrm{~m}^{-1}$ were used. Intermittent contact mode imaging was used to obtain the AFM images.

The 1:49:50 C18/C8/TEOS xerogel was allowed to equilibrate for $48 \mathrm{~h}$ in ASW and was then imaged in ASW using contact mode AFM imaging. Images were obtained using silicon nitride AFM tips (Veeco, MLCT) with a nominal spring constant of $100 \mathrm{pn}$ $\mathrm{nm}^{-1}$.

\section{Surface energy analysis}

Contact angles were measured for all xerogel formulations with a contact angle goniometer [Rame-Hart, Model NRL 100] at room temperature using the sessile drop technique. The xerogel films were stored in air prior to characterization and measurements were performed in air as previously described (Baier and Meyer 1992; Tang et al. 2005, Bennett et al. 2010). Up to 13 different diagnostic liquids were used including water, glycerol, formamide, thiodiglycol, methylene iodide, 1-bromonaphthalene, 1-methylnaphthalene, dicyclohexyl, $n$-hexadecane, $n$-tridecane, $n$-decane, $n$ octane, and $n$-heptane. The liquid/vapor surface tensions of these liquids were determined using data obtained with a ring tensiometer (Cenco-duNuoy). The technique of "advanced angle" analysis was used (Baier and Meyer 1992). Zisman plots were constructed by plotting the cosine of the average angle measured for each liquid against the liquid/vapor surface tension of the diagnostic liquid (Zisman 1964; Baier and Meyer 1992). A linear least squares analysis was performed to determine the critical surface tension $\left(\gamma_{\mathrm{C}}\right)$ of the sample at the $\cos \theta=1$ axis. The data were also treated as described by Kaelbe (1970) and Nyilas et al. (1977) to give the surface free energy $\left(\gamma_{\mathrm{S}}\right)$ (Baier 
and Meyer 1992). For the 2:48:50 C18/C8/TEOS and 4:46:50 C18/C8/TEOS xerogels, values of $\gamma_{\mathrm{S}}$ were estimated using methylene iodide and water according to the method of Owens and Wendt (1969).

\section{Biofouling assays with barnacles}

Barnacle cypris larvae were obtained from Duke University Marine Laboratory. Glass controls were acid washed in $10 \% \mathrm{HCl}$ for $2 \mathrm{~h}$, rinsed well with deionized water, and allowed to dry completely prior to cyprid settlement. Silastic ${ }^{\mathbb{R}}$ T2 coated slides $c a$ $500 \mu \mathrm{m}$ in thickness, provided by $\mathrm{Dr}$ AB Brennan, University of Florida (Schumacher et al. 2007), were included in the assays to provide a standard FR coating.

\section{Cyprid settlement assays}

Approximately $5 \mathrm{ml}$ of seawater were added to each xerogel-coated Petri dish. This volume covered the bottom of the dish and allowed the cyprids free range of movement across the surface. A 400- $\mu$ l drop of seawater containing between 30 and 60 2-4-day-old barnacle cypris larvae was then added to each of the dishes. The PDMSE (Silastic T2) standard on glass microscope slides could not be completely immersed. A $400-\mu l$ drop of seawater containing between 20 and 40 2-4-day-old cypris larvae was added to the PDMSE surfaces. The larvae were allowed to settle for $48 \mathrm{~h}$ at which time the percentage of barnacles that settled in each dish was counted. The average percentage settlement for each of the experimental coatings was then compared to the glass and polystyrene standards. The concurrent settlement on the PDMSE (Silastic T2) standard was used as a positive control for larval metamorphic competence.

\section{Barnacle removal assays}

A 400- $\mu$ l drop of seawater containing between 20 and 40 2-4-day-old cypris larvae was placed on the xerogel surface coated on glass microscope slides. The surfaces with larvae were placed in a constant temperature incubator at $25^{\circ} \mathrm{C}$ on a $12 \mathrm{~h}: 12 \mathrm{~h}$ light:dark cycle and larvae were allowed to settle for $48 \mathrm{~h}$. Newly metamorphosed juveniles on their respective coatings were transferred to growth chambers and kept in the incubator where they were fed the unicellular green alga Dunaliella tertiolecta and the diatom Skeletonema costatum for 2 weeks, and then a mixture of D. tertiolecta, S. costatum, and naupliar larvae of Artemia sp. for an additional week. Juveniles were then transferred to a 16-1 aquarium tank in an automated rack system with temperature, salinity, and $\mathrm{pH}$ monitors and programmed for a $10 \%$ daily water change. Barnacles in the tank were fed a $500-\mathrm{ml}$ flask of Artemia sp. three times a week for 4-6 weeks, which is the time it took the juvenile barnacles to reach a basal plate diameter of $3-5 \mathrm{~mm}$, the minimum size necessary to conduct force gauge tests according to ASTM D 5618.

The procedures for critical removal stress were followed from ASTM D 5618 with the following modifications: (1) the force measuring device was operated by a motorized stand, thus insuring a constant application of force during dislodgement, and (2) barnacle dislodgement studies from coatings were performed under water. The apparatus consists of an IMADA ZP-11 digital force gauge (11.2lb) mounted on an IMADA SV-5 motorized stand. The slides were clamped into a custom-built Plexiglas chamber that allowed their complete submersion during dislodgement tests.

Juvenile barnacles were selected for testing based on healthy appearance and minimum size requirements. Only barnacles occurring at least $5 \mathrm{~mm}$ from the edges of the slide were tested. Other barnacles in close proximity to the test subject were removed if they could potentially interfere with measurements. Prior to removal of barnacles each basal plate was photographed using a Canon ${ }^{\mathrm{TM}}$ EOS 10D camera attached to an Olympus ${ }^{\mathrm{TM}}$ SZX12 dissecting microscope, and images were calculated using NIH's ImageJ. After photographs were taken, the slide was clamped into the Plexiglas chamber. The force gauge mounted on the motorized stand was used to apply a shear force to the base of the barnacles at a rate of approximately $4.5 \mathrm{~N}$ $\mathrm{s}^{-1}$ until the organism was detached. Force was applied parallel to the film surface. The force required for detachment was noted and observations were made as to the mode of failure. If any portion of the base of the organism was left attached to the substratum, the test was deemed void for removal. The surfaces were examined visually for damage to the xerogel film caused by barnacle removal and by stereomicroscope if there were any ambiguity. The critical removal stress was calculated by dividing the force ( $\mathrm{F}$, Newtons) required to remove the test subject by the area of attachment $\left(\mathrm{A}, \mathrm{mm}^{2}\right)$. For barnacles where a portion of the base of the organism was left attached to the substratum, the remaining basal plate was photographed and the exact percentage remaining after testing $(\% \mathrm{BPR})$ was calculated with digital image analysis.

\section{Biofouling assays with Ulva}

Coatings applied to glass slides were equilibrated in circulating deionized water for $24 \mathrm{~h}$ prior to the start 
of assays with the alga. One hour prior to the assay, the slides were transferred to ASW. Silastic T2 coated slides $c a 500 \mu \mathrm{m}$ in thickness, provided by $\mathrm{Dr} \mathrm{AB}$ Brennan, University of Florida (Schumacher et al. 2007), were included in the assays to provide a standard FR coating.

\section{Settlement of zoospores of Ulva}

Fronds of Ulva linza were collected from Llantwit Major, Wales $\left(51840^{\prime} \mathrm{N} ; 3848^{\prime} \mathrm{W}\right)$ and a spore suspension of $1.5 \times 10^{6}$ spores $\mathrm{ml}^{-1}$ prepared by the method of Callow et al. (1997). Three replicate slides of each treatment were placed in individual wells of "quadriperm" polystyrene culture dishes (Greiner) and $10 \mathrm{ml}$ of spore suspension were added. Dishes were incubated in the dark for $1 \mathrm{~h}$ at $\sim 20^{\circ} \mathrm{C}$. After incubation the slides were gently washed in ASW to remove unattached (swimming) spores. Slides were fixed in 2.5\% glutaraldehyde. The density of spores attached to the surfaces was counted using an image analysis system attached to a fluorescence microscope. Spores were visualized by autofluorescence of chlorophyll. Counts were made for 30 fields of view (each $0.17 \mathrm{~mm}^{2}$ ), $1 \mathrm{~mm}$ apart over the central region of each slide, using image analysis software (Imaging Associates Ltd.) attached to a Zeiss epifluorescence microscope (Callow et al. 2002). Spore settlement data are expressed as the mean number of spores adhered per $\mathrm{mm}^{2}$ with $95 \%$ confidence limits $(n=90)$.

\section{Adhesion strength of sporelings of Ulva}

Spores were allowed to settle as described above. After washing away unattached spores, spores that had attached to the test surfaces were cultured in dishes containing supplemented seawater medium that was changed every 2 days (Starr and Zeikus 1987). The dishes were placed in an illuminated incubator $(75 \mathrm{~mW}$ $\mathrm{m}^{-2} \mathrm{~s}^{-1}$ incident irradiation) for 7 days during which time the spores germinated and developed into sporelings (young plants).

The biomass produced was quantified by measuring the fluorescence of chlorophyll in a Tecan fluorescence plate reader (excitation $=430 \mathrm{~nm}$, emission $=670 \mathrm{~nm})($ Finlay et al. 2008a). Fluorescence was measured as relative fluorescence units (RFU) and was directly proportional to the quantity of biomass present. The RFU value for each slide was the mean of 70 point fluorescence readings taken from the central region.

Sporeling adhesion strength was determined by exposing the slides to an impact pressure of $54 \mathrm{kPa}$ from an automated water jet, which traversed the central region of each slide (Finlay et al. 2002). Three replicate slides of each coating were used in the analysis. The biomass that remained in the sprayed area after exposure to the water jet was quantified as described above. Percentage removal of sporelings was determined by comparison of the biomass (RFU) before exposure with that remaining attached to the coatings after exposure to the water jet.

\section{Results}

\section{Characterization of xerogel surfaces}

Figure 1 presents IR microscopy images of the 50:50 C8/TEOS (panels a and b) and 1:49:50 C18/C8/TEOS (panel $\mathrm{c}$ and $\mathrm{d}$ ) xerogel films integrating the hydrocarbon region $\left(2800-3000 \mathrm{~cm}^{-1}\right)$. The spatial resolution for the insets of panels a and $\mathrm{c}$ and panels $\mathrm{b}$ and $\mathrm{d}$ $(150 \mu \mathrm{m} \times 150 \mu \mathrm{m}$ images $)$ is $2.7 \mu \mathrm{m}$. Figure 1a also shows the extracted IR spectra from five regions of the integrated image of the 50:50 C8/TEOS xerogel. Figure 1c shows extracted IR spectra from three indicated regions of the integrated image of the $1: 49: 50 \mathrm{C} 18 / \mathrm{C} 8 /$ TEOS xerogel: the high-absorbance and low-absorbance regions as well as one from a "flat" region. Segregation of the more hydrophobic component (larger IR absorbance) in the 1:49:50 C18/C8/TEOS xerogel film is clearly indicated in Figure 1c and d. The sol gel process produces xerogels with residual silanol functionality (3200-3700 $\mathrm{cm}^{-1}$; Figure 1, panels a and b) which is uniformly distributed across the $50: 50 \mathrm{C} 8 /$ TEOS and 1:49:50 C18/C8/TEOS xerogel surfaces
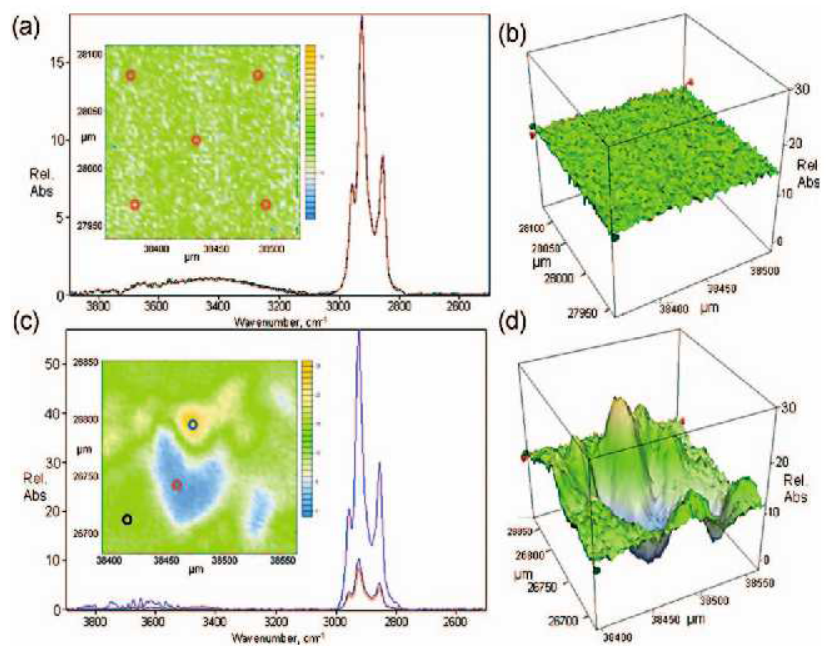

Figure 1. Imaging transmission IR microscopy results for the 50:50 C8/TEOS xerogel (panels a, b) and 1:49:50 C18/C8/ TEOS xerogel (panels c, d) films. Panels b and d show 3-D profiles for $150 \mu \mathrm{m} \times 150 \mu \mathrm{m}$ regions of each xerogel integrating the IR signal between $2800 \mathrm{~cm}^{-1}$ and $3000 \mathrm{~cm}^{-1}$ (hydrocarbon region). Panels a and c illustrate the extracted spectra from those regions marked on the contour plot insets. The contour plot insets in panels a and $\mathrm{c}$ correspond to the 3-D plots in panels $\mathrm{b}$ and $\mathrm{d}$, respectively. 
(IR microscopy images not shown). However, the hydrocarbon signal is significantly more homogeneous across the 50:50 C8/TEOS sample in comparison to the 1:49:50 C18/C8/TEOS sample.

Figure 2 shows AFM topographic images $(1 \mu \mathrm{m} \times$ $1 \mu \mathrm{m}$ ) of the 50:50 C8/TEOS (panel a), 4:46:50 C18/ C8/TEOS (panel b), 3:47:50 C18/C8/TEOS (panel c), and 2:48:50 C18/C8/TEOS (panel d) xerogel surfaces after immersion in ASW for $1 \mathrm{~h}$, rinsing with distilled water, and air drying for 2-h. A pattern of nanopores is apparent on the 2:48:50 C18/C8/TEOS xerogel surface that is not apparent on the other surfaces. A $5 \mu \mathrm{m} \times$ $5 \mu \mathrm{m}$ image of the 1:49:50 C18/C8/TEOS xerogel surface after immersion in ASW for $1 \mathrm{~h}$, rinsing with distilled water, and air drying for 2 -h is shown in Figure 3a indicating a pattern of larger nanopores (in comparison to the 2:48:50 C18/C8/TEOS xerogel) over the entire surface. Profilometry of several of the nanopores of Figure 3a indicated a depth of 2-7 nm and widths on the order of $100-400 \mathrm{~nm}$.

A $5 \mu \mathrm{m} \times 5 \mu \mathrm{m} \mathrm{AFM} \mathrm{image} \mathrm{of} \mathrm{the} \mathrm{1:49:50} \mathrm{C18/}$ C8/TEOS xerogel surface after immersion in ASW for $48 \mathrm{~h}$ and imaging in ASW is shown in Figure 3b. As described below, the 1:49:50 C18/C8/TEOS xerogel surface has equilibrated with ASW after $48 \mathrm{~h}$. The nanopores are less pronounced, but still apparent and larger structural features on the order of $2-3 \mu \mathrm{m}$ across and $\pm 2-3 \mathrm{~nm}$ in height/depth are more pronounced in Figure $3 b$ relative to Figure $3 a$.
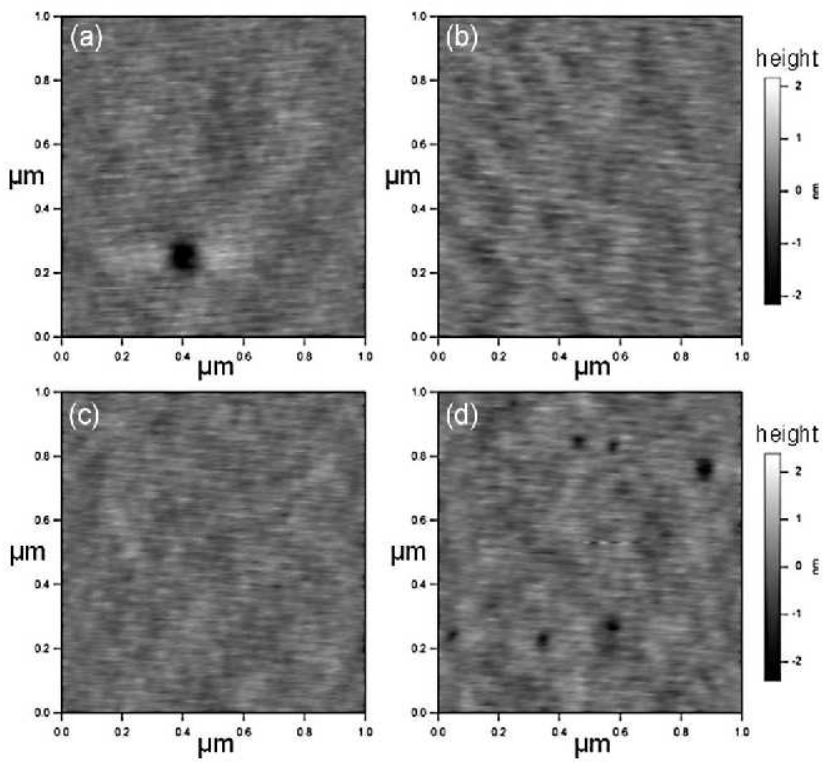

Figure 2. AFM height images of (a) 50:50 C8/TEOS, (b) 4:46:50 C18/C8/TEOS, (c) 3:47:50 C18/C8/TEOS, and (d) 2:48:50 C18/C8/TEOS xerogels after immersion in ASW for $1 \mathrm{~h}$, rinsing with distilled water, and air drying for $2 \mathrm{~h}$. Image size: $1 \mu \mathrm{m} \times 1 \mu \mathrm{m}$. Z-range: $\pm 2 \mathrm{~nm}$.
The roughness of the surfaces shown in Figures 2 and $3 \mathrm{a}$ was calculated by measuring the root mean square roughness $\left(R_{\mathrm{rms}}\right)$ on five $1-\mu \mathrm{m} \times 1-\mu \mathrm{m}$ images for each sample, where $R_{\mathrm{rms}}$ is defined as the root mean square average of the topographic deviations $(t)$ as shown in Equation (1):

$$
R_{\mathrm{rms}}=\sqrt{\frac{1}{N} \sum_{i=1}^{N}\left(t_{i}-\bar{t}\right)^{2}} .
$$

Values of $R_{\mathrm{rms}}$ are compiled in Table 1. The 50:50 C8/ TEOS, 4:46:50 C18/C8/TEOS, and 3:47:50 C18/C8/ TEOS surfaces had a very low surface roughness $(<0.25 \mathrm{~nm})$ when the surfaces had been immersed in ASW for $1 \mathrm{~h}$, rinsed with distilled water, and air dried for 2-h (Table 1). The 2:48:50 C18/C8/TEOS and 1:49:50 C18/C8/TEOS surfaces display increased values of $R_{\mathrm{rms}}(0.67 \pm 0.03$ and $1.15 \pm 0.04 \mathrm{~nm}$, respectively, Table 1).

Values of $\gamma_{\mathrm{C}}$ and $\gamma_{\mathrm{S}}$ were determined for surfaces stored in air by comprehensive contact angle analysis. The 50:50 C8/TEOS and the C18/C8/TEOS xerogel surfaces have similar values of $\gamma_{\mathrm{C}}\left(21.3-22.4 \mathrm{mN} \mathrm{m}^{-1}\right)$ and $\gamma_{\mathrm{S}}\left(22.8-27.1 \mathrm{mN} \mathrm{m}^{-1}\right)$ as shown in Table 1 . Measured values of $\gamma_{\mathrm{C}}$ for the xerogel surfaces are quite similar to $\gamma_{\mathrm{C}}$ for PDMSE $\left(23 \mathrm{mN} \mathrm{m}^{-1}\right)$ (Brady and Singer 2000; Feinberg et al. 2003).

Prior to the comprehensive contact angle analysis, the xerogel films were stored in air for several weeks until values of $\theta_{\mathrm{Ws}}$ were no longer increasing and measurements were also performed in air as previously described (Baier and Meyer 1992; Tang et al. 2005; Bennett et al. 2010). The static water contact angles, $\theta_{\mathrm{Ws}}$, for all of the C18-containing xerogel coatings were higher in comparison to $\theta_{\mathrm{Ws}}$ for the 50:50 C8/TEOS coating $\left[(100 \pm 1)^{\circ}\right.$, Table 1$]$ with the 1:49:50 C18/C8/
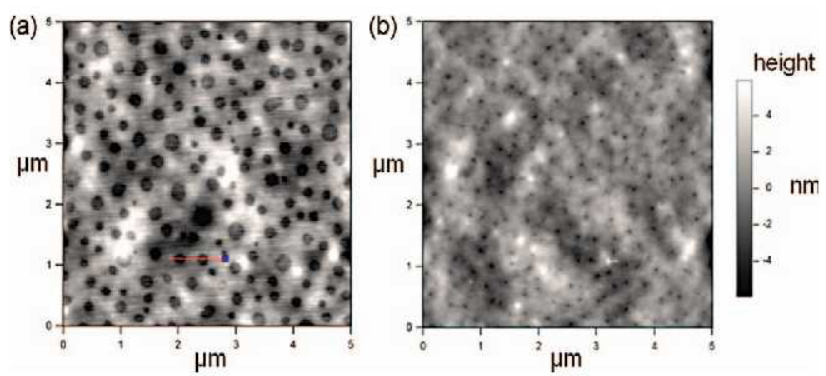

Figure 3. AFM height image of the 1:49:50 C18/C8/TEOS xerogel (a) after immersion in ASW for $1 \mathrm{~h}$, rinsing with distilled water, and air drying for $2 \mathrm{~h}$ and (b) after immersion in ASW for $48 \mathrm{~h}$ and imaging in ASW. Image sizes: $5 \mu \mathrm{m} \times$ $5 \mu \mathrm{m}$. Z-range: $\pm 5 \mathrm{~nm}$. 
Table 1. Static water contact angles $(\theta \mathrm{ws})$, critical surface tensions $(\gamma \mathrm{C})$, surface energies $(\gamma \mathrm{S})$, and surface roughness as determined by AFM for selected xerogel surfaces.

\begin{tabular}{lcccc}
\hline Sample & $\theta \mathrm{Ws}$ & $\gamma \mathrm{c}^{\mathrm{b}}, \mathrm{mN} \mathrm{m}^{-1}$ & $\gamma \mathrm{s}^{\mathrm{b}}, \mathrm{mN} \mathrm{m}^{-1}$ & Surface roughness $^{\mathrm{c}}, \mathrm{nm}^{\mathrm{r}}$ \\
\hline Glass & $21 \pm 1$ & $33.5^{\mathrm{d}}$ & - & - \\
PDMSE & $109^{\mathrm{d}}$ & $23.0 \pm 0.4^{\mathrm{e}}$ & - & - \\
50:50 C8/TEOS & $100 \pm 2$ & $21.3 \pm 0.1$ & $27.1 \pm 0.3$ & $0.24 \pm 0.02$ \\
5:45:50 C18/C8/TEOS & $108.2 \pm 0.9$ & $21.9 \pm 0.3$ & $24.6 \pm 0.9$ & - \\
4:46:50 C18/C8/TEOS & $105 \pm 2$ & - & $22.8 \pm 1.1^{\mathrm{f}}$ & $0.20 \pm 0.01$ \\
3:47:50 C18/C8/TEOS & $102 \pm 4$ & $22.4 \pm 0.9$ & $25.7 \pm 2.1$ & $0.22 \pm 0.02$ \\
2:48:50 C18/C8/TEOS & $108.3 \pm 0.9$ & - & $22.8 \pm 1.1^{\mathrm{f}}$ & $0.67 \pm 0.03$ \\
1:49:50 C18/C8/TEOS & $111.2 \pm 0.2$ & $21.4 \pm 0.1$ & $24.8 \pm 1.1$ & $1.15 \pm 0.04$ \\
\hline
\end{tabular}

${ }^{a}$ Mean of five independent measurements for coatings stored in air prior to measurement. \pm one SD. ${ }^{b}$ Mean of two independent measurements for coatings stored in air prior measurement. ${ }^{\mathrm{c}}$ Average of five replicate measurements. \pm one SD. ${ }^{\mathrm{d}}$ From Tang et al. (2005). ${ }^{\mathrm{e}}$ From Feinberg et al. (2003). ${ }^{\mathrm{f}}$ Method of Owens and Wendt (1969).

TEOS coating having the highest value of $\theta_{\mathrm{Ws}}$ $\left[(111.2 \pm 0.2)^{\circ}\right.$, Table 1].

The 50:50 C8/TEOS and 1:49:50 C18/C8/TEOS xerogel coatings were immersed in ASW for various periods of time to examine the impact of the aqueous environment on $\theta_{\mathrm{Ws}}$. Following immersion in ASW, the xerogel films were rinsed with distilled water, dried with a stream of argon (filtered through DriRite ${ }^{\mathbb{R}}$ ) at ambient temperature for $2 \mathrm{~min}$ prior to contact angle measurement. For the 50:50 C8/TEOS xerogel, $\theta_{\mathrm{Ws}}$ was unchanged after 4-h immersion in ASW $\left[(99 \pm 2)^{\circ}\right]$, decreased to $(93 \pm 2)^{\circ}$ after $24 \mathrm{~h}$ of immersion, to $(87 \pm 1)^{\circ}$ after immersion for $48 \mathrm{~h}$, and remained constant with longer immersion times (up to 1 week). For the 1:49:50 C18/C8/TEOS xerogel, the value of $\theta_{\mathrm{Ws}}$ decreased to $(104 \pm 1)^{\circ}$ after immersion for $4 \mathrm{~h}$ in ASW and to $(96 \pm 1)^{\circ}$ after immersion for $24 \mathrm{~h}$ in ASW where it remained constant.

The "recovery" of the 1:49:50 C18/C8/TEOS xerogel surface following immersion in an aqueous environment was examined with surfaces that had been soaked in deionized water. The value of $\theta_{\mathrm{Ws}}$ decreased from $(110 \pm 1)^{\circ}$ prior to immersion in deionized water to $(87 \pm 2)^{\circ}$ after immersion for 1 week. Upon standing in air at ambient temperature, values of $\theta_{\mathrm{Ws}}$ increased with time returning to pre-immersion values $\left(>107^{\circ}\right)$ after 4 weeks.

Values of $\gamma_{\mathrm{S}}$ were estimated for the 50:50 C8/TEOS and 1:49:50 C18/C8/TEOS xerogels following immersion in ASW using the method of Owens and Wendt (1969) with water and methylene iodide contact angles. Prior to immersion in ASW, values of $\gamma_{\mathrm{S}}$ were $27.1 \pm 0.3 \mathrm{mN} \mathrm{m}^{-1}$ for the $50: 50 \mathrm{C} 8 /$ TEOS xerogel surface and $24.8 \pm 1.1 \mathrm{mN} \mathrm{m}^{-1}$ for the 1:49:50 C18/ C8/TEOS xerogel surface (Table 1). Following immersion in ASW, $\gamma_{\mathrm{S}}$ increased to $35.2 \pm 0.7 \mathrm{mN} \mathrm{m}^{-1}$ for the 50:50 C8/TEOS xerogel surface over the 48-h to $96-$ $\mathrm{h}$ immersion window and $25.6 \pm 1.1 \mathrm{mN} \mathrm{m}^{-1}$ for the

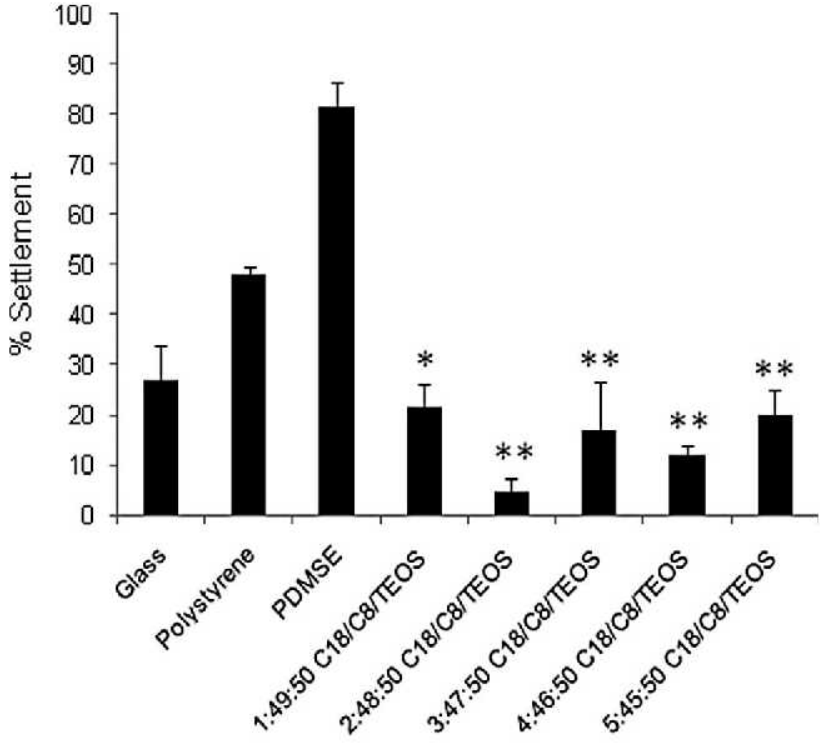

Figure 4. Settlement of barnacle cypris larvae on xerogel coatings applied to glass dishes, polystyrene, and glass standards. Each value is the mean from three replicate measurements. Error bars represent the SE of the mean. * = Values which are significantly lower than the polystyrene standard; ${ }^{* *}=$ values which are significantly lower than the glass and polystyrene standards. The average settlement from a drop assay onto PDMSE slides that were settled concurrently is also included as a control for metamorphic competence, but was not included in the statistical analysis due to the different assay type.

1:49:50 C18/C8/TEOS xerogel surface over the 24-h to 96-h immersion window.

\section{Settlement of cypris larvae and removal of juvenile barnacles of $\mathrm{B}$. amphitrite}

The settlement of 2-4-day-old barnacle cypris larvae that were placed on the xerogel, glass, and polystyrene surfaces was compared as shown in Figure 4. The average settlement from a drop assay onto PDMSE 
(Silastic T2) slides that were settled concurrently is also included as a standard for metamorphic competence. There was a significant difference in the settlement of cypris larvae amongst the coatings (ANOVA, $F=7.733, p=0.0008$ ). Settlement on the 1:49:50 C18/C8/TEOS xerogel was significantly lower in comparison to the polystyrene standard and settlement on the $2: 48: 50,3: 47: 50,4: 46: 50$, and 5:45:50 C18/C8/ TEOS xerogels were all significantly lower in comparison to glass and polystyrene standards. The PDMSE

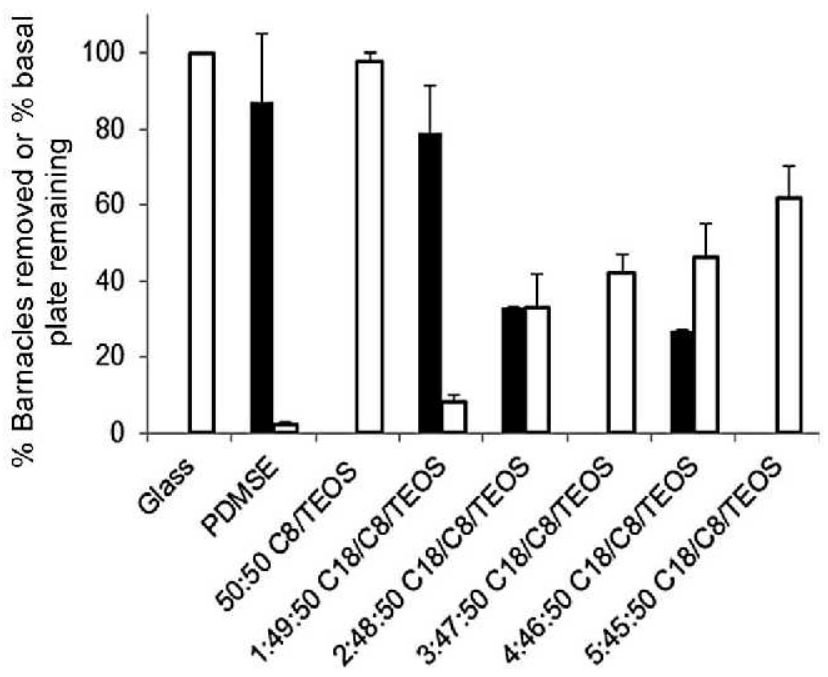

Figure 5. Percentage of juvenile barnacles removed completely via shear pressure ( $\boldsymbol{\square})$ and percentage of barnacle basal plate remaining from those barnacles removed completely or incompletely $(\square)$. Total number of barnacles, $n$, removed in each group and critical removal stress for barnacles removed completely are given in Table 2 . Error bars are the SE from the mean.
(Silastic T2) slides were not included in the statistical analysis due to the different assay type (a "drop" assay onto the surface as opposed to an "immersion" assay of the entire surface.)

The strength of attachment of juvenile barnacles to the five $\mathrm{C} 18 / \mathrm{C} 8 / \mathrm{TEOS}$ xerogel surfaces, the 50:50 C8/ TEOS xerogel and glass and PDMSE (Silastic T2) standards was measured via force-gauge measurements with forces applied in shear. Only the 1:49:50 C18/C8/ TEOS (15/19 barnacles removed completely), 2:48:50 C18/C8/TEOS (7/21 barnacles removed completely), and 4:46:50 C18/C8/TEOS (4/15 barnacles removed completely) xerogel surfaces and the PDMSE (Silastic T2) standard (13/15 barnacles removed completely) performed as FR surfaces (Figure 5, Table 2). Removal of juvenile barnacles from the 1:49:50 C18/ C8/TEOS xerogel was similar in comparison to the PDMSE (Silastic T2) standard. The percentage of barnacles that were removed completely from the 1:49:50 C18/C8/TEOS xerogel films averaged $(79 \pm 12) \%$ for each of the five replicate surfaces while the PDMSE (Silastic T2) standard averaged $(87 \pm 18) \%$ for each of the five replicate surfaces.

The critical removal stress (CRS) for the 1:49:50 C18/C8/TEOS, 2:48:50 C18/C8/TEOS, and 4:46:50 $\mathrm{C} 18 / \mathrm{C} 8 / \mathrm{TEOS}$ xerogel surfaces was $0.20-0.21 \mathrm{~N}$ $\mathrm{mm}^{-2}$, which was somewhat higher in comparison to the removal force for the PDMSE (Silastic T2) standard $\left(0.15 \mathrm{~N} \mathrm{~mm}^{-2}\right.$, Table 2). There were no significant differences in CRS amongst the 1:49:50 C18/C8/TEOS, 2:48:50 C18/C8/TEOS, and 4:46:50 $\mathrm{C} 18 / \mathrm{C} 8 / \mathrm{TEOS}$ xerogel surfaces. However, on all coatings except for the 4:46:50 C18/C8/TEOS xerogel, the average CRS values were significantly higher than the

Table 2. Density of attached zoospores, sporeling biomass, percentage removal of 7-day sporeling growth with a water impact pressure of $54 \mathrm{kPa}$, percentage removal of juvenile barnacles, critical removal stress, and percentage basal plate remaining for barnacles partially or completely removed for xerogel surfaces and glass and PDMSE (Silastic T2) standards.

\begin{tabular}{|c|c|c|c|c|c|c|}
\hline \multirow[b]{2}{*}{ Sample } & \multicolumn{3}{|c|}{ Ulva settlement/growth } & \multicolumn{3}{|c|}{ Barnacle removal-complete and partial } \\
\hline & $\begin{array}{c}\text { Spore } \\
\text { density }^{\mathrm{a}}, \\
\text { no. } \mathrm{mm}^{-2}\end{array}$ & $\begin{array}{c}\text { Sporeling } \\
\text { biomass }^{\mathrm{b}} \text {, } \\
\text { RFU }\end{array}$ & $\begin{array}{c}\% \\
\text { Removal }^{\mathrm{c}} \text {, }\end{array}$ & $\begin{array}{c}\text { Complete } \\
\text { removal } / n \\
(\% \text { removal })^{\mathrm{d}}\end{array}$ & $\begin{array}{c}\mathrm{CRS}^{\mathrm{e}}, \\
\mathrm{N} \mathrm{mm}^{-2}\end{array}$ & $\begin{array}{l}\mathrm{BPR}^{\mathrm{f}}, \\
\%(\mathrm{n})\end{array}$ \\
\hline Glass & $90 \pm 11$ & $2000 \pm 300$ & $21 \pm 3$ & $0 / 12(0)$ & NA & $100(12)$ \\
\hline PDMSE & $182 \pm 19$ & $4100 \pm 300$ & $73 \pm 4$ & $13 / 15(87)$ & $0.15 \pm 0.01$ & $2 \pm 1(15)$ \\
\hline $50: 50 \mathrm{C} 18 / \mathrm{C} 8 / \mathrm{TEOS}$ & $98 \pm 8$ & $1900 \pm 200$ & $75 \pm 6$ & $0 / 21(0)$ & NA & $98 \pm 2(21)$ \\
\hline 5:45:50 C18/C8/TEOS & $752 \pm 45$ & $7800 \pm 300$ & $37 \pm 6$ & $0 / 13(0)$ & NA & $62 \pm 8(13)$ \\
\hline 4:46:50 C18/C8/TEOS & $495 \pm 31$ & $8800 \pm 400$ & $31 \pm 5$ & $4 / 15(27)$ & $0.21 \pm 0.02$ & $46 \pm 9(15)$ \\
\hline $3: 47: 50 \mathrm{C} 18 / \mathrm{C} 8 / \mathrm{TEOS}$ & $390 \pm 35$ & $7900 \pm 300$ & $89 \pm 4$ & $0 / 02(1)$ & NA & $42 \pm 5(20)$ \\
\hline 2:48:50 C18/C8/TEOS & $529 \pm 28$ & $8700 \pm 300$ & $51 \pm 9$ & $7 / 21(33)$ & $0.21 \pm 0.02$ & $33 \pm 9(21)$ \\
\hline 1:49:50 C18/C8/TEOS & $635 \pm 31$ & $8400 \pm 300$ & $30 \pm 4$ & $15 / 19(79)$ & $0.20 \pm 0.02$ & $8 \pm 4(19)$ \\
\hline
\end{tabular}

${ }^{a}$ Each value is the mean from 90 counts on three replicate slides. $\pm 95 \%$ confidence limits. ${ }^{b}$ Sporeling biomass data are expressed as the mean $\mathrm{RFU}$ of three replicate slides; $\pm \mathrm{SE}$ of the mean. ${ }^{\mathrm{c} P e r c e n t}$ removal of 7-day-old sporelings with a surface water pressure $54 \mathrm{kPa}$ from 50:50 C8/ TEOS and C18/C8/TEOS hybrid xerogel coatings. ${ }^{\mathrm{d}}$ Number of juvenile barnacles completely removed with $n$ as the total number of barnacles removed. ${ }^{\mathrm{e}}$ Average critical removal stress (CRS); $\pm \mathrm{SE}$ of the mean. ${ }^{\mathrm{f}}$ Average percentage of basal plate remaining after barnacle removal with $n$ as the total number of barnacles removed; $\pm \mathrm{SE}$ of the mean. 
average CRS of the PDMSE (Silastic T2) standard (ANOVA $p=0.0371$ ). Barnacles on all other coatings and the glass standard broke when force was applied to them in shear, and left a complete or partial basal plate attached to the surface.

Berglin et al. (2001) suggest that the remaining fraction of the basal plate left on a surface appears to be a function of barnacle bioadhesive bond strength and that it could be used as a measure of the efficacy of FR coatings. For barnacles not completely removed, the percentage of the basal plate remaining was calculated with digital image analysis. These results were combined with data for barnacles completely removed ( $0 \%$ basal plate remaining) and are compiled in Table 2 and shown in Figure 5. There was a significant difference in the average percentage of basal plate retained (\% BPR) between surfaces (KruskalWallis $p<0.0001)$. Post hoc testing showed that the average \% BPR for the glass and 50:50 C8/TEOS standards were significantly higher than all other coatings and that these surfaces retained essentially all of the basal plate (100 and $98 \%$, respectively). The PDMSE (Silastic T2) standard had the lowest average $\%$ BPR but it showed no significant difference from the 1:49:50 and 2:48:50 $\mathrm{C} 18 / \mathrm{C} 8 /$ TEOS xerogel coatings. However, the 2:48:50 C18/C8/TEOS xerogel was not significantly different from the 3:47:50, 4:46:50, and 5:45:50 C18/C8/TEOS xerogel surfaces, which were all significantly higher than the PDMSE (Silastic T2) standard. Although \% BPR increased as the C18 content increased from 2 to 5 mol- $\%(33-62 \%)$, the differences were not statistically significant.

\section{Settlement and removal of zoospores of Ulva}

Settlement of zoospores and growth of sporeling biomass and removal on the xerogel surfaces and glass and PDMSE (Silastic T2) standards were examined (Table 2, Figure 6). One-way analysis of variance and Tukey tests showed that the number of settled spores was significantly lower on PDMSE (Silastic T2), glass, and the 50:50 C8/TEOS xerogel than on the C18containing xerogels (F 7, 712=298 $p<0.05$ ). Amongst the C18-containing xerogels, settlement was significantly lower on the $3: 47: 50$ C18/C8/TEOS xerogel.

\section{Strength of attachment of sporelings of Ulva}

Sporelings grew well and after 7 days, a green covering was visible on all surfaces. Sporeling growth tracked the density of settled zoospores and sporeling growth amongst all the C18/C8/TEOS xerogels was comparable (Table 2). The percentage removal of 7-day sporeling biomass from the test surfaces with a water

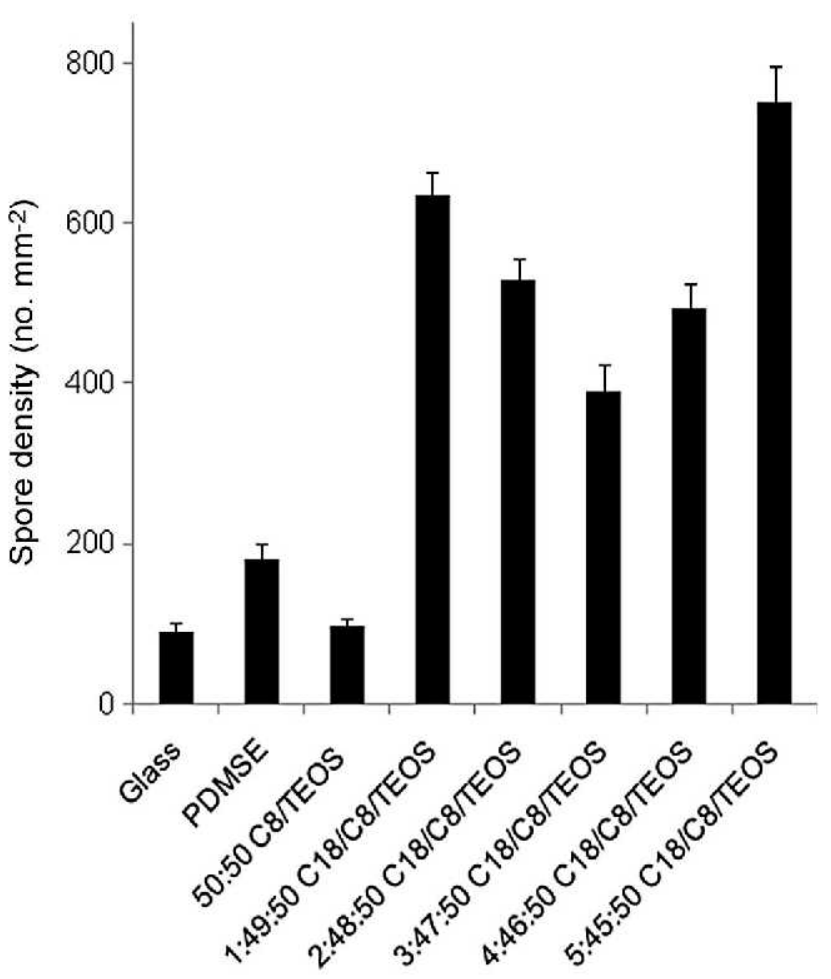

Figure 6. Settlement of zoospores of Ulva on xerogel coatings and glass and PDMSE standards. Each value (from Table 2) is the mean of 90 counts on each of three replicate slides. Error bars represent the 95\% confidence limits.

pressure of $54 \mathrm{kPa}$ is compiled in Table 2 and is shown in Figure 7. Sporelings adhered most strongly to the glass standard where only $21 \%$ of the sporeling biomass was removed. The strength of attachment of sporelings was weakest on the 3:47:50 C18/C8/TEOS xerogel $(89 \%$ removal). One-way analysis of variance $\left(\mathrm{F}_{7,16}=21.3, p<0.05\right)$ showed that the samples were split into two groups with the 2:48:50 C18/C8/TEOS xerogel ( $51 \%$ removal) being intermediate between the two. The 50:50 C8/TEOS xerogel, the 3:47:50 C18/C8/ TEOS xerogel, and the PDMSE (Silastic T2) standard formed one group (73-89\% removal) and the 1:49:50 C18/C8/TEOS xerogel, the $4: 46: 50 \mathrm{C} 18 / \mathrm{C} 8 / \mathrm{TEOS}$ xerogel, the 5:45:50 C18/C8/TEOS xerogel, and the glass standard formed the second group (21-37\% removal). Removal from the $2: 48: 50 \mathrm{C} 18 / \mathrm{C} 8 / \mathrm{TEOS}$ xerogel was similar to all samples except for the 3:47:50 C18/C8/TEOS xerogel and the glass standard.

\section{Discussion}

Earlier studies of xerogel surfaces suggest that twoand three-component xerogels provide very uniform and homogeneous surfaces (Tang et al. 2005; Bennett et al. 2010; Finlay et al. 2010). SEM studies of the 50:50 C8/TEOS xerogel as well as several other xerogel 


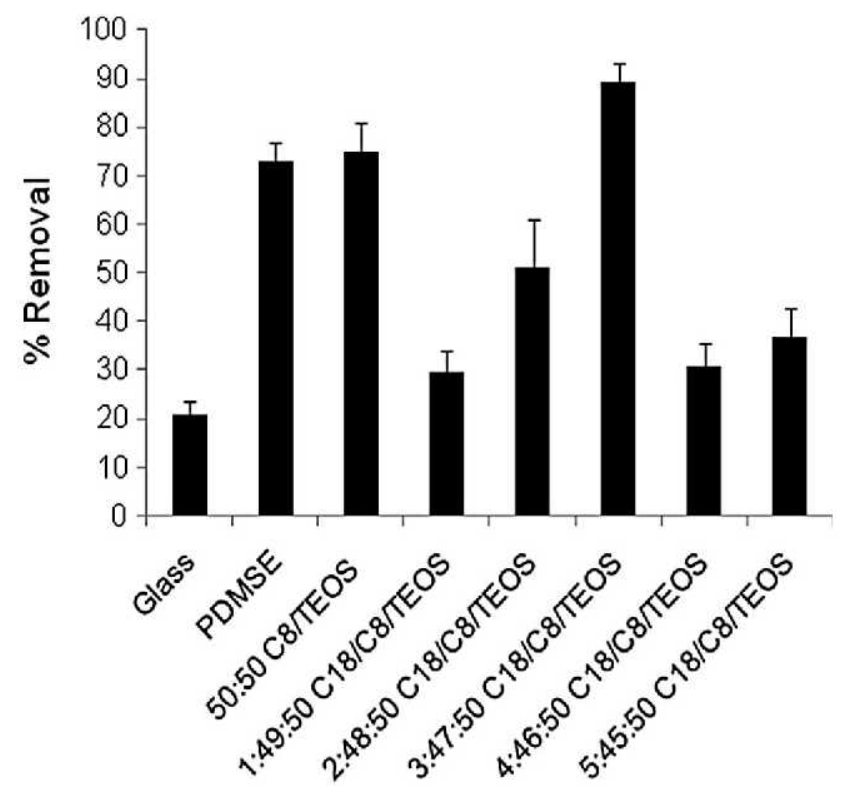

Figure 7. Percentage removal of 7-day-old sporelings of Ulva from xerogel coatings and glass and PDMSE standards with a water-jet pressure of $54 \mathrm{kPa}$. Each value (from Table 2 ) is the mean from three replicate slides. Error bars represent the SE from the mean.

surfaces indicate that these surfaces are uniform, uncracked, and topographically smooth when dry (Bennett et al. 2010). AFM measurements on the same series of xerogels submerged in ASW show very low surface roughness $(\leq 0.8 \mathrm{~nm})$. Time-of-flight, secondary-ion mass spectrometry (ToF-SIMS) studies show that there was no phase segregation of fluorocarbon and hydrocarbon groups on the $\mu \mathrm{m}$ scale in a 25:25:50 trifluoropropyltrimethoxysilane/C8/TEOS xerogel (Bennett et al. 2010). The 50:50 C8/TEOS, 50:50 C3/TEOS and 5:45:50 C18/C8/TEOS xerogel surfaces have nearly identical values of $\gamma_{\mathrm{C}}$ and $\gamma_{\mathrm{S}}$ (Bennett et al. 2010).

In the current study, the incorporation of 1-5 mole$\% \mathrm{C} 18$ in the C8/TEOS sol (a relatively small change in formulation) substantially impacted the distribution of chemical functionality on the xerogel surface (from transmission IR microscopy images) and the surface topography (AFM studies). The IR images of the 50:50 C8/TEOS and 1:49:50 C18/C8/TEOS xerogels films shown in Figure 1 show that the hydrocarbon signal is significantly more homogeneous across the 50:50 C8/ TEOS sample in comparison to the 1:49:50 $\mathrm{C} 18 / \mathrm{C} 8 /$ TEOS sample, where some segregation of hydrocarbon components is clearly indicated. These IR images could represent clusters of smaller hydrocarbon-rich features/domains seen more clearly in the AFM images. In the AFM images of Figures 2 and 3a where the surfaces have been exposed to ASW for $1 \mathrm{~h}$ and then imaged in air, the addition of 1 and 2 mole- $\%$ C18 to the sol formulation yielded xerogel surfaces characterized by increased surface roughness (Table 1) and by the spontaneous formation of nanopores of the order of $100-400 \mathrm{~nm}$ across and 2-7 nm deep. After equilibration with ASW, the AFM images of the 1:49:50 C18/C8/TEOS xerogel surface (Figure $3 b$ ) still show the presence of nanopores (although of smaller diameter, perhaps due to swelling of the surface upon exposure to water) but also clearly show a regular pattern of $2-3 \mu \mathrm{m}$ features $\pm 2-3 \mathrm{~nm}$ in height/depth. These structural features have not been observed in other xerogel formulations that the authors have examined.

The dimensions of the nanopores in the AFM images are much smaller than the $2.7-\mu \mathrm{m}$ resolution of the IR microscopy images, where spatial resolution is essentially limited by the diffraction limit, so it is difficult to compare directly (overlay) the structural features. However, it is clear that the small changes in formulation substantially impact the distribution of chemical functionality, as well as the surface topography. In spite of these differences, values of $\gamma_{C}$ (21.4 $\left.22.4 \mathrm{mN} \mathrm{m}^{-1}\right)$ and $\gamma_{\mathrm{S}}\left(22.8-25.7 \mathrm{mN} \mathrm{m}^{-1}\right)$ are identical within statistical error within the series of $\mathrm{C} 18 / \mathrm{C} 8$ / TEOS xerogels in this study for surfaces stored in air (Table 1). Measured values of $\gamma_{C}$ for the C18/C8/TEOS xerogel surfaces are quite similar to $\gamma_{\mathrm{C}}$ for the 50:50 C8/TEOS xerogel $\left(21.3 \mathrm{mN} \mathrm{m}^{-1}\right.$, Table 1$)$ and $\gamma_{\mathrm{C}}$ for PDMSE $\left(23 \mathrm{mN} \mathrm{m}^{-1}\right)$ (Brady and Singer 2000; Feinberg et al. 2003) and are all within the 20$25 \mathrm{mN} \mathrm{m}^{-1}$ range, where minimal bioadhesion has been reported due to the formation of weak boundary layers between the surface and the adhesives of fouling organisms (Baier et al. 1968; Baier 1984).

The values of $\gamma_{C}$ and $\gamma_{S}$ described in the paragraph above are all for surfaces that had been stored in air prior to contact angle measurement. For the 1:49:50 C18/C8/TEOS xerogel, immersion in ASW for 24 to $96 \mathrm{~h}$ gave surfaces with no significant differences in $\gamma_{\mathrm{S}}$ $\left(25.6 \pm 1.1 \mathrm{~m} \mathrm{~N} \mathrm{~m}^{-1}\right)$ relative to surfaces stored in air $\left(24.8 \pm 1.1 \mathrm{~m} \mathrm{~m}^{-1}\right)$. This is in contrast to the behavior of the 50:50 C8/TEOS where $\gamma_{\mathrm{S}}$ increased significantly from $27.1 \pm 0.3 \mathrm{mN} \mathrm{m}^{-1}$ for surfaces stored in air to $35.2 \pm 0.7 \mathrm{mN} \mathrm{m}^{-1}$ for surfaces immersed 48 to $96 \mathrm{~h}$ in ASW.

Although the 50:50 C8/TEOS and 1:49:50 C18/C8/ TEOS xerogels underwent some surface reorganization upon immersion in an aqueous environment as indicated by the drop in $\theta_{\mathrm{Ws}}$ for both surfaces, the reorganization was reversible. Contact angles returned to pre-immersion values upon standing in the air indicating that no irreversible chemical or structural changes had occurred to either of the surfaces upon wetting.

It can be speculated with respect to the differences observed in the distribution of surface functionality 
and topography in the 1:49:50 C18/C8/TEOS xerogel and the remaining $\mathrm{C} 18 / \mathrm{C} 8 /$ TEOS xerogels and the 50:50 C8/TEOS xerogel. Through increased London forces (the "hydrophobic effect"), interactions among the $\mathrm{C} 18$ molecules during sol formation might lead to preferential formations of islands of higher $\mathrm{C} 18$ density. With 2 mole- $\%$ or less $\mathrm{C} 18$ in the formulation, these islands were significantly discrete to impact the surface topography. At higher $\mathrm{C} 18$ concentrations, segregation in the sol is still possible, but interactions among the $\mathrm{C} 18$ groups led to a more uniform surface following xerogel formation. Values of $\theta_{\mathrm{Ws}}$ increased over several weeks from the time of coating to their final value given in Table 1 suggesting that the initial surface was not in its final state and matured with time. "Untangling" of the $\mathrm{C} 18$ islands followed by formation of more uniform $\mathrm{C} 18-\mathrm{C} 18$ or C18-C8 interactions perhaps led to less surface roughness at higher $\mathrm{C} 18$ concentrations.

The 1:49:50 C18/C8/TEOS xerogel surface segregated alkane functionality as indicated by transmission IR microscopy. Transmission IR microscopy, as a surface characterization technique, complements more commonly used methods such as SEM, AFM, ToFSIMS, and x-ray photoelectron spectroscopy (XPS). Transmission IR microscopy images show the distribution of functional groups on a surface and the integrated spectra quantify the density of functional groups. The technique provides additional details of surface nanostructure that will inform the development of future AF and FR coatings.

Initial studies with the barnacle $B$. amphitrite suggest that the differences in topography and distribution of chemical functionality among the C18/C8/TEOS xerogels significantly impacts the settlement and/or release of this fouling organism in comparison to one another and in comparison to the 50:50 C8/TEOS xerogel as shown in Figures 4 and 5. For barnacles, the greatest impact is observed with respect to the removal of juvenile barnacles where the 1:49:50 C18/C8/TEOS xerogel and the PDMSE (Silastic T2) standard are statistically identical for the complete removal of the barnacle and all its basal plate (Figure 5, Table 2). However, values of the critical removal stress (CRS) are not statistically different (Table 2) in comparing barnacle removal from the 1:49:50 C18/C8/TEOS, 2:48:50 C18/C8/TEOS, and 4:46:50 C18/C8/TEOS xerogel surfaces and only the CRS value for the 4:46:50 C18/C8/TEOS xerogel is not significantly different from the PDMSE (Silastic T2) standard (ANOVA $p=0.0371$, Table 2). For those barnacles that were not removed completely, a partial basal plate remained behind and the two surfaces that released the highest percentage of juvenile barnacles retained the smallest fraction of basal plate for all barnacles removed (completely and incompletely): $8 \%$ for the 1:49:50 C18/C8/TEOS xerogel and $2 \%$ for the PDMSE (Silastic T2) standard (Table 2).

Biological evaluation is imperfect because of variability in the various organisms under study. The reason why some barnacles are removed completely and why others are only partially removed is attributable to variability in the coating, variability in the barnacle adhesive, and variability in the structural integrity of the barnacle (Berglin et al. 2001). All are involved to some degree, but there is no way to tease apart the relative contribution of the different factors resulting in basal plate breakage. In this study, the 1:49:50 C18/C8/TEOS xerogel and the PDMSE (Silastic T2) standard are statistically equivalent for the removal of barnacles - completely or partially.

The equivalence of the 1:49:50 C18/C8/TEOS xerogel and the PDMSE (Silastic T2) standard in this study is somewhat surprising since the xerogel surfaces were thin $(<5 \mu \mathrm{m}$ thickness $)$ and had a relative high modulus (60 MPa for the 50:50 C8/TEOS xerogel, Bennett et al. 2010) in comparison to the PDMSE (Silastic T2) standard with a thickness of approximately $500 \mu \mathrm{m}$ and a low elastic modulus of $0.6 \mathrm{MPa}$ (Feinberg et al. 2003). The 1:49:50 C18/C8/TEOS xerogel was unlikely to follow Brady-Singer fracture mechanics, which is thought to be the major mode of barnacle release for PDMSE coatings (Brady and Singer 2000; Chaudhury et al. 2005). The surface topography of the 1:49:50 C18/C8/TEOS xerogel on both the $\mathrm{nm}$ and the $\mu \mathrm{m}$ scale is unlike the surface topography of other xerogels examined to date. In the absence of features that favor Brady-Singer fracture mechanics, the relationship of surface topography and the adhesive strength of barnacle cements may be speculated upon.

With Ulva, differences in topography and distribution of chemical functionality amongst the $\mathrm{C} 18 / \mathrm{C} 8 /$ TEOS xerogels also impacted settlement of zoospores and removal of sporeling biomass, but the best performance was exhibited by the $3: 47: 50 \mathrm{C} 18 / \mathrm{C} 8 /$ TEOS xerogel, not the 1:49:50 C18/C8/TEOS xerogel that performed well with barnacles. Following exposure to a water pressure of $54 \mathrm{kPa}$, removal of sporeling biomass from the $3: 47: 50 \mathrm{C} 18 / \mathrm{C} 8 / \mathrm{TEOS}$ xerogel was significantly greater in comparison to the glass standard and the remaining C18/C8/TEOS xerogels (Table 2, Figure 7). Removal of sporeling biomass from the 3:47:50 C18/C8/TEOS xerogel was not significantly different in comparison to removal from the 50:50 C8/TEOS xerogel and the PDMSE (Silastic T2) standard. The similarity of sporeling adhesion to the PDMSE (Silastic T2) standard and 50:50 C8/TEOS xerogel has been previously observed (Bennett et al. 2010). Settlement of zoospores on the 
3:47:50 C18/C8/TEOS xerogel was significantly lower in comparison to the other C18/C8/TEOS xerogels of this study (Figure 6), but incorporation of $\mathrm{C} 18$ into the formulation gave xerogel surfaces that showed significantly increased zoospore settlement relative to either the 50:50 C8/TEOS xerogel formulation or the PDMSE (Silastic T2) standard.

While opposing trends in the settlement and release of different fouling organisms make it difficult to design a single surface to minimize settlement of all fouling organisms, xerogels can be fine-tuned to provide surfaces with different water wettability and critical surface tension/surface energy (Cho et al. 2002; Tang et al. 2005; Bennett et al. 2010; Finlay et al. 2010). The topography of the xerogel surfaces can also be fine-tuned by the incorporation of small amounts of a long-chain alkyl component as shown by the C18/ C8/TEOS xerogels of this study. The formulation and coating of these xerogel-based surfaces require no special attention or preparation (pre-patterning). Overall, xerogel surfaces have high potential as FR or easyclean materials (Finlay et al. 2010).

\section{Acknowledgements}

The authors thank the Office of Naval Research for supporting this research through grants to M. E. C. and J. A. C. (award N00014-08-1-0010), D. E. W. (award N0001409-1-0350), G. C. W. (award N00014-05-10765), and F. V. B. and M. R. D. (award N0014-09-1-0217).

\section{References}

Ainslie KM, Sharma G, Dyer MA, Grimes CA, Pishko MV. 2005. Attenuation of protein adsorption on static and oscillating magnetostrictive nanowires. Nano Lett 5: $1853-1856$.

Akesso L, Pettitt ME, Callow JA, Callow ME, Stallard J, Teer D, Liu C, Wang S, Zhao Q, D'Souza F, et al. 2009. The potential of nano-structured silicon oxide type coatings deposited by PACVD for control of aquatic biofouling. Biofouling 25:55-67.

Aldred N, Scardino A, Cavaco A, de Nys R, Clare AS. 2010. Attachment strength is a key factor in the selection of surfaces by barnacle cyprids (Balanus amphitrite) during settlement. Biofouling 26:287-299.

Baier RE. 1984. Initial events in microbial film formation. In: Costlow JD, Tipper RC, editors. Marine biodeterioration: an interdisciplinary study. Annapolis: US Naval Institute Press. p. 57-62.

Baier RE, Meyer AE. 1992. Surface analysis of foulingresistant marine coatings. Biofouling 6:165-180.

Baier RE, Shaffin EG, Zisman WA. 1968. Adhesion: mechanisms that assist or impede it. Science 162: $1360-1368$.

Beigbeder A, Degee P, Conlan SL, Mutton RJ, Clare AS, Pettitt ME, Callow ME, Callow JA, Dubois P. 2008. Preparation and characterisation of silicone-based coatings filled with carbon nanotubes and natural sepiolite and their application as marine fouling-release coatings. Biofouling 24:291-302.
Bennett SM, Finlay JA, Gunari N, Wells DD, Meyer AE, Walker GC, Callow ME, Callow JA, Bright FV, Detty MR. 2010. The role of surface energy and water wettability in aminoalkyl/fluorocarbon/hydrocarbon-modified xerogel surfaces in the control of marine biofouling. Biofouling 26:235-246.

Berglin M, Larsson A, Jonsson PR, Gatenholm P. 2001. The adhesion of the barnacle, Balanus improvisus, to poly (dimethylsiloxane) fouling-release coatings and poly (methyl methacrylate) panels: the effect of barnacle size on strength and failure mode. J Adhesion Sci Technol 15:1485-1502.

Bernards MT, Cheng G, Zhang Z, Shengfu C, Jiang S. 2008. Nonfouling polymer brushes via surface-initiated, twocomponent atom transfer radical polymerization. Macromolecules 41:4216-4219.

Brady RF, Singer IL. 2000. Mechanical factors favoring release from fouling release coatings. Biofouling 15: 73-81.

Callow ME, Callow JA, Pickett-Heaps JD, Wetherbee R. 1997. Primary adhesion of Enteromorpha (Chlorophyta, Ulvales) propagules: quantitative settlement studies and video microscopy. J Phycol 33:938-947.

Callow ME, Jennings AR, Brennan AB, Seegert CE, Gibson A, Wilson L, Feinberg A, Baney R, Callow JA. 2002. Microtopographic cues for settlement of zoospores of the green fouling alga Enteromorpha. Biofouling 18: 237-245.

Chaudhury MK, Chung JY, Finlay JA, Callow ME, Callow JA. 2005. The influence of elastic modulus and thickness on the release of the soft-fouling green alga Ulva linza (syn. Enteromorpha linza) from poly(dimethylsiloxane) (PDMS) model networks. Biofouling 21:41-48.

Cho E-J, Tao Z, Tang Y, Tehan EC, Bright F, Hicks WL Jr, Gardella, Jr, JA, Hard R. 2002. Tools to rapidly produce and screen biodegradable polymer and sol-gel-derived xerogel formulations. Appl Spectrosc 56:1385-1389.

Cole MA, Voelcker NH, Thissen H, Griesser HJ. 2009. Stimuli-responsive interfaces and systems for the control of protein-surface and cell-surface interactions. Biomaterials $30: 1827-1850$.

de Vasconcelos C, Bezerril P, Dantas T, Periera M, Fonseca J. 2007. Adsorption of bovine serum albumin on template-polymerized chitosan/poly(methacrylic acid) complexes. Langmuir 23:7687-7694.

Feinberg AW, Gibson AL, Wilkerson WR, Seegert CA, Wilson LH, Zhao LC, Baney RH, Callow JA, Callow $\mathrm{ME}$, Brennan AB. 2003. Investigating the energetics of bioadhesion on microengineered siloxane elastomers: characterizing the topography, mechanical properties, and surface energy and their effect on cell contact guidance. In: Clarson SJ, Fitzgerald JJ, Owen MF, Smith SD, van Dyke ME, editors. Synthesis and properties of silicones and silicone-modified materials. Am Chem Soc 838:196-211.

Finlay JA, Fletcher BR, Callow ME, Callow JA. 2008a. Effect of background colour on growth and adhesion strength of Ulva sporelings. Biofouling 24:219-225.

Finlay JA, Callow ME, Schultz MP, Swain GW, Callow JA. 2002. Adhesion strength of settled spores of the green alga Enteromorpha. Biofouling 18:251-256.

Finlay JA, Krishnan S, Callow ME, Callow JA, Dong R, Asgill N, Wong K, Kramer EJ, Ober CK. 2008b. Settlement of Ulva zoospores on patterned fluorinated and PEGylated monolayer surfaces. Langmuir 24: 503-510. 
Finlay JA, Bennett SM, Brewer LH, Sokolova A, Clay G, Gunari N, Meyer AE, Walker GC, Wendt DE, Callow ME, et al. 2010. Barnacle settlement and the adhesion of protein and diatom microfouling to xerogel films with varying surface energy and water wettability. Biofouling 27:657-666.

Genzer J, Efimenko K. 2006. Recent developments in superhydrophobic surfaces and their relevance to marine fouling: a review. Biofouling 22:339-360.

Genzer J, Marmur A. 2008. Biological and synthetic selfcleaning surfaces. MRS Bull 33:742-746.

Grozea CM, Walker GC. 2009. Approaches in designing non-toxic polymer surfaces to deter marine biofouling. Soft Matter 5:4088-4100.

Grozea CM, Gunari N, Finlay JA, Callow ME, Callow JA, Lu Z-H, Walker GC. 2009. Water-stable biblock polystryrene-block-poly(2-vinyl pyridine) and diblock polystyrene-block-poly (methyl methacrylate) cylindrical patterned surface inhibit settlement of zoospores of the green alga Ulva. Biomacromolecules 10:1004-1012.

Gudipati CS, Finlay JA, Callow JA, Callow ME, Wooley KL. 2005. The antifouling and fouling-release performance of hyperbranched fluoropolymer (HBFP)-poly (ethylene glycol) (PEG) composite coatings evaluated by adsorption of biomacromolecules and the green fouling alga Ulva. Langmuir 21:3044-3053.

Hucknall A, Rangarajan S, Chilkoti A. 2009. In pursuit of zero: polymer brushes that resist the adsorption of proteins. Adv Mater 21:2441-2446.

Kaelble DH. 1970. Dispersion-polar surface tension properties of organic solids. J Adhesion 2:66.

Koc Y, de Mello AJ, McHale G, Newton MI, Roach P, Shirtcliffe NJ. 2008. Nano-scale superhydrophobicity: suppression of protein adsorption and promotion of flow-induced detachment. Lab Chip 8:582-586.

Krishnan S, Ayothi R, Hexemer A, Finlay JA, Sohn KE, Perry R, Ober CK, Kramer EJ, Callow ME, Callow JA, et al. 2006. Anti-biofouling properties of comblike block copolymers with amphiphilic side chains. Langmuir 22:5075-5086.

Krishnan S, Weinman CJ, Ober CK. 2008. Advances in polymers for anti-biofouling surfaces. J Mater Chem 18:3405-3413.

Lee J, Chu BH, Chen KH, Ren F, Lele TP. 2009. Randomly oriented, upright $\mathrm{SiO}_{2}$ coated nanorods for reduced adhesion of mammalian cells. Biomaterials 30:4488-4493.

Long CJ, Schumacher JF, Robinson PAC II, Finlay JA, Callow ME, Callow JA, Brennan AB. 2010. A model that predicts the attachment behaviour of Ulva linza zoospores on surface topography. Biofouling 26:411-419.

Majumdar P, Lee E, Patel N, Ward K, Stafslien SJ, Daniels J, Boudjouk P, Callow ME, Callow JA, Thompson SEM. 2008. Combinatorial materials research applied to the development of new surface coatings IX: An investigation of novel anti-fouling/fouling-release coatings containing quaternary ammonium salt groups. Biofouling 24:185-200.

Martinelli E, Menghetti S, Galli G, Glisenti A, Krishnan S, Paik MY, Ober CK, Smilgies D-M, Fischer DA. 2009. Surface engineering of styrene/PEGylated-fluoroalkylstyrene block copolymer thin films. J Polymer Sci A. Polymer Chem 47:267-284.
McMaster DM, Bennett SM, Tang Y, Finlay JA, Kowalke GL, Nedved B, Bright FV, Callow ME, Callow JA, Wendt DE, et al. 2009. Antifouling character of 'active' hybrid xerogel coatings with sequestered catalysts for the activation of hydrogen peroxide. Biofouling 25:21-33.

Mi L, Bernards MT, Cheng G, Yu Q, Jiang S. 2010. pH responsive properties of non-fouling mixed-charge polymer brushes based on quartenary amine and carboxylic acid monomers. Biomaterials 31:2919-2925.

Nyilas E, Morton WA, Cumming RD, Lederman DM, Chiu TH, Baier RE. 1977. Effects of polymer surface molecularstructure and force-field characteristics on blood interfacial phenomena. 1. J Biomed Mat Res 11:51-68.

Owens DK, Wendt RC. 1969. Estimation of the surface free energy of polymers. J Appl Polymer Sci 13:1741-1747.

Piola RF, Dafforn KA, Johnston EL. 2009. The influence of antifouling practices on marine invasions. Biofouling 25:633-644.

Scardino AJ, Zhang H, Cookson DJ, Lamb RN, deNys R. 2009. The role of nanoroughness in antifouling. Biofouling 25:749-756.

Schultz MP. 2007. Effects of coating roughness and biofouling on ship resistance and powering. Biofouling 23:331-341.

Schultz MP, Bendick JA, Holm ER, Hertel WM. 2010. Economic impact of biofouling on naval surface ships. Biofouling 27:87-98.

Schumacher JF, Carman ML, Estes TG, Feinberg AW, Wilson LH, Callow ME, Callow JA, Finlay JA, Brennan AB. 2007. Engineered antifouling microtopographies effect of feature size, geometry, and roughness on settlement of zoospores of the green alga Ulva. Biofouling 23:55-62.

Selvaggio P, Tusa S, Detty MR, Bright FV, Ciriminna R, Pagliaro M. 2009. Ecofriendly protection from biofouling of the monitoring system at Pantelleria's Cala Gadir underwater archaeological site, Sicily. Int J Naut Arch $38: 417-421$

Spori DM, Drobek T, Zürcher S, Spencer ND. 2010. Cassiestate wetting investigated by means of a hole-to-pillar density gradient. Langmuir 26:9465-9473.

Starr RC, Zeikus JA. 1987. UTEX - The culture collection at the University of Texas. J Phycol 23Suppl:S1-S27.

Tang Y, Finlay JA, Kowalke GL, Meyer AE, Bright FV, Callow ME, Callow JA, Wendt DE, Detty MR. 2005. Hybrid xerogel films as novel coatings for antifouling and fouling release. Biofouling 21:59-71.

Thomas KV, Brooks S. 2010. The environmental fate and effects of antifouling paint biocides. Biofouling 26:73-88.

Weinman CJ, Finlay JA, Park D, Paik MY, Krishnan S, Sundaram HS, Dimitriou M, Sohn KE, Callow ME, Callow JA, et al. 2009. ABC triblock surface active block copolymer with grafted ethoxylated fluoroalkyl amphiphilic side chains for marine antifouling/fouling-release applications. Langmuir 25:12266-12274.

Zisman WA. 1964. Relation of the equilibrium contact angle to liquid and solid constitution. In: Fowkes FM, editor. Contact angle wettability and adhesion. Vol. 43. Adv Chem Ser. Washington, DC: Am Chem Soc. p. 1-51. 